\title{
An Investigation into the Perceived Job Satisfaction of Employees in a Telemarketing Center due to the Introduction of a New System
}

\author{
Nndwambi Paul Bulwana ${ }^{1}$, Prof. René Pellissier ${ }^{2}$ \\ ${ }^{I}$ Department of Business Studies, Management College of Southern Africa (MANCOSA) \\ ${ }^{2}$ Department of Business Studies, Management College of Southern Africa (MANCOSA)
}

\begin{abstract}
The aim of the research study was to determine whether the electronic business system implemented by the organisation is working sufficiently and whether employees using the system are satisfied with its use or not, as well as determining possible challenges experienced. The research method used to gather the data was qualitative. The study concluded that, in order for the selected organisation to gain competitive advantage and adapt to the dramatic changing environment, it is important that the organisation achieve management efficiency by increasing employee satisfaction. The study further concluded that, during the implementation of the system, major improvements became visible in that employees were operating at higher efficiencies than before. It is safe to say that the changes brought about by management with regard to the implementation of the new system had a positive impact on employees' productivity and the organisational profit. The organisation must continue to provide employees with the necessary training in order for them to achieve set company goals and not be demoralised. The organisation should continue to empower employees to embrace the new system implemented, for it to be a success.
\end{abstract}

Keywords: telemarketing, employee satisfaction, organisational profit

\section{Introduction}

Perceived organisational support (POS) refers to an employee's perceptions concerning the extent to which the organisation values their contributions and cares about their well-being (Carter, 2011). In dealing with the concept of organisational behaviour, perception becomes important because people's behaviours are based on their perception of what reality is, and not on reality itself (Robbins, 2004). The study conducted was selected on the basis that, for any organisation that needs to be in the forefront in this cut-throat, competitive and rapidly changing business environment, it is important to ensure that employees are satisfied and operating at a level at which the organisation can be able to fend off any competition they might be facing or be likely to face. The outcomes of this study are applicable to any other such environment that is fast-paced and where information needs to be delivered timeously.

\subsection{Research Context: Background}

In any organisation, when a new system is introduced for implementation, most users either decide to adopt the new system, or resist the implementation of the new system based on their evaluation of change associated with such a system and what the new system will provide them and their needs (Trkman,2010). In order to improve the company's operational efficiency and to maintain the competitiveness in the market place, an insurance corporate company has continued to invest substantially in their IT capacity by introducing and implementing the electronic business solution system, known as the eBiz system. According to Ozcelik (2010:221) BPR is defined as "the fundamental rethink and radical redesign of business processes to achieve dramatic improvements in critical contemporary measures of performance, such as cost, quality, service, and speed". Pressures organisations face relate to the fundamental rethink and radical redesign of an entire business system to achieve significant improvements in the performance of the company which is what the company did when they introduced their electronic business solution. Therefore, the company engaged in the process of BPR when they introduced their electronic business solution (eBiz). The Electronic Business Solution (eBiz) was introduced in 1996, with the specific objective of transforming the company and its business units. The customer base of the new system is not confined to the company only, but to other business partners and their customers. Proper processes in any organisation sometimes become a cause for concern and, as a consequence of implementing the electronic business solution, it became necessary for the organisation to re-invent their ways and that is precisely what the company did in order to remain competitive. The new system could assist in implementing new business processes, business finance related transactions and document exchange. The eBiz system offers the company an opportunity to distribute information speedily and maximise productivity. The system uses a combination of private and public domain channels in order to save time and maximise 
productivity. Job satisfaction is considered to be the measure of an employee's satisfaction or contention with their work (Carter, 2011). The easiest and most often used way of measuring job satisfaction, is through the use of scales that record an employee's reactions and responses to his/her job (Kabir: 2011). Robins and Judge (2009:65) define job satisfaction as a "positive feeling about one's job resulting from an evaluation of its characteristics". Dessler (2010) is of the opinion that job satisfaction plays a critical role in determining an individual's performance. Individuals who are performing above their job profiles assist the organisation to attain its strategic set targets and remain competitive in the industry it is operating. Diaz-Serrano and Cabral Vieira (2005) are of the opinion that job satisfaction is a good indicator of an overall individual well-being and can also be an indicator of possible employee turnover. Job satisfaction can be described as the feelings that an employee has about his job (Okoye, 2011). McShane and Von Glinow (2005), describe job satisfaction as a multi-faceted concept that encompasses past and present feelings which results in gratifying results when an evaluation of one's job is done. Job satisfaction can also be described as the extent to which an individual is content with gratifications bestowed on him as part of his performance (Statt, 2004). According to Armstrong (2006), job satisfaction was defined as the feelings and attitudes individuals have over their jobs. Spector (2006) is of the opinion that job satisfaction is reflected on the way people feel about what they are doing overall in their jobs. Blyton and Jenkins (2007:106) argue that, despite its wide usage in scientific research studies, there has never been any general consensus as to what extent job satisfaction entails. The manner in which business operated in the insurance industry in South Africa was based on an insurance consultant having to approach a potential client with a business proposal to sell that person an investment or insurance policy. In order for the company to be competitive and not rely on insurance consultants to sell their products to potential clients, who have to fill in massive forms, send for approvals and wait for a few weeks before a policy can be issued. The company was forced to transform and begin to offer products and services by introducing the electronic business systems (eBiz).The implementation of the telemarketing centre formed part of this transformation. The study focused on the perceived employee job satisfaction due to the introduction and implementation of the electronic business solution and tries to determine how employees of the company have embraced the new system. Part of the reasons why process improvement programmes are undertaken in an organisation is to try and close the performance gaps the company is facing using the traditional way of operating. The challenge the company might encounter as it starts with the process of reengineering the organisational operational processes is the resistance that might arise from employees who do not want to see change and the study will try to identify factors that will have an impact on the outcome of system improvement to be undertaken by the organisation and gauge their perceived willingness to use the new system being implemented. The perception of any successful business process reengineering stems from user satisfaction on the new system and the technology acceptance model. The employee attitudes and beliefs towards the new system to be implemented determine its user satisfaction.

\subsection{Research Problem}

It is widely reported that IT in any business is regarded as an important business asset which facilitates any transformational change in any organisation (Mohapatra, 2013). Gibson (2003) indicates that IT is an important factor in any organisation that requires radical change. In fact, it has been shown by Cohen and Golan (2007) that failure of most IT projects is the result of user resistance to the implementation of the new system in the organisation. The company was previously focusing on doing business using the postal system. Before the electronic business system was in use, consultants or agents used to contact about 500 people per day, but, since the installation of the new system, this has increased to 2000 new prospective customers per day.

\subsection{Research Questions}

Research questions guide the researcher to a particular method (Donalek, 2005:124). This research seeks to investigate, and get an understanding, on employees' perceptions with regard to the electronic business solution (eBiz) that was implemented by the company in order to gauge:

- What is the level of employee satisfaction and the perceived usefulness of the telemarketing system in the Direct Marketing Division?

- What are the job factors that influence employee satisfaction as a result of the perceived ease of use of the telemarketing system?

- What are the challenges experienced by employees when using the telemarketing system?

- What is the extent of satisfaction with their jobs after the introduction of the new system?

\subsection{Significance of the Study}

The value of this research study is the critical valuation of the levels of job satisfaction amongst employees after the implementation of the electronic business systems in the BPR. An analysis of factors the organisation can focus on which factors may assist the management team in drafting policies with an emphasis 
on enhancing the level of employee job satisfaction will be looked at, as well as ways in which the company goals and objectives can be achieved. Indeed, the outcomes of the study may be beneficial to similar organisations employing IT in the process redesign based on the need for new systems, and having to deal with the perceptions on the ease of use from the employees' point of view, as this may impact on the job satisfaction of the employees, and therefore of the organisation's growth.

\section{Literature Review}

Technology is a transformation process that forces organisations to adapt to a changing environment and assist to integrate its systems and communication. In a challenging business environment, organisations constantly try to find new ways to remain competitive (Hellriegel, Jackson, Slocum, Staude, Amos, Klopper, Louw and Oosthuizen, 2009). An organisation needs to determine and understand which drivers of success are needed in order to maximize on investment. Organisations in any industry are directly affected by at least five competitive forces: rivals, new entrants, substitute goods and services, customers and suppliers (Hellriegel, et al. 2009). People's perceptions also impact on their acceptance of technology in the workplace. User resistance to information systems implementation has been identified as the salient reason for the failure of new systems and as a result needs to be understood and managed correctly (Markus 2004). According to Bergh and Geldenhuys (2014), the Technology Acceptance Model (TAM) is designed to measure the relative importance of user perceptions of the system based on two factors, the usefulness and ease of use in their adoption of employee behaviour. The Perceived usefulness refers to the degree to which a person believes that using a particular system would enhance his job performance (Bergh and Geldenhuys, 2014). The Perceived ease of use is the degree to which a person believes that using a particular system would be free from any effort (Bergh and Geldenhuys, 2014). The Intention to use is an individual belief that influences his intentions and intentions influence one action (Ajzen, 2002). The TAM has proven to be useful in understanding how people accept technology and continue in its use. The Tam further suggests that users will put up with any difficulty in using the system provided that the system provides some critical function.

\subsection{Relevance and Definitions of Job Satisfaction}

The issue of job satisfaction becomes important when noting that the business environment has become increasingly complex and the marketplace has changed from a local setting to a global one. If employees are engaging in extra role playing and are enjoying a sense of job satisfaction, they may experience a higher level of commitment to their organisation than those who have not benefited from using the technology (Bergh and Geldenhuys, 2014). Organisational failure to meet customers' demand and/or expectations forces customers to shift to other service providers (Heizer and Render, 2011). Therefore, organisations have been working hard to improve their business processes in order to improve or maintain their services for retaining and/or attracting more customers. The advancement in new technology forces organisations to modernise their processes, thereby fostering their competitive advantages (Laudon and Laudon, 2006). Organisations therefore have to continuously realign their operations to meet all these challenges by being responsive to the customer and competitors. However, how individuals perceive their work context is critical in shaping their job attitudes and behaviours (Rosen, Chang, Johnson and Levy, 2009). When analysing job satisfaction, the logic stems from the premise that a satisfied employee is a happy employee and a happy employee is a successful employee. Satisfaction weaves through many situations as a desirable attitude indicates success to the extent that it leads to sought-after intentions and behaviours (Fishbein and Ajzen 2010). Job satisfaction, as a general concept, depends on the agreement between an individual's totality of attitudes, interests, behavioural patterns, emotional responses, social roles, and other individual traits that endure over long period of time (Rothman and Cooper, 2008:59). Herzberg believed workers were more satisfied with their jobs when they experienced certain intrinsic factors including: responsibility granted on the job, actual type of work done, the feeling of achievement from work performed and their potential to advance within the organisation (Judge, Podsakoff, Shaw and Rich, 2010). Job satisfaction is a worker's sense of achievement and success on the job. It is generally perceived to be directly linked to productivity as well as to personal well-being. Job satisfaction implies doing a job one enjoys, doing it well and being rewarded for one's efforts. Job satisfaction further implies enthusiasm and happiness with one's work. Job satisfaction is the key ingredient that leads to recognition, income, promotion and achievement of other goals that lead to a feeling of fulfilment (Kaliski, 2007). Job satisfaction relates to an employee's personal evaluation of jobs against those issues that are essentially considerable to them. As emotions and feelings are involved in such assessments, employees' levels of job satisfaction may impact significantly on their personal, social and work lives, and as such, also influence their behaviours at work, (Sempane, Rieger and Roodt, 2002). Spector (2006) states that a successful organisation is one with satisfied workers. A satisfied employee is a committed employee, an employee who has the intention to remain with the organisations due to the perceived job satisfaction and organisational support. Spector continues to mention that 
job satisfaction is a concept based on the premise that the happiest worker is also the most productive worker and that, to people happy in their work, their job does not feel as if it is work at all.

\subsection{Factors of Job Satisfaction}

Intrinsic factors: These are individual internal desires to perform a particular job facet. Intrinsically motivated employees are bound to perform a particular task only because it gives them pleasure and not for a reward (Kassin, 2006). Rickli (2010) is of the opinion that a higher intrinsic motivation will increase job performance and effort on a longer term. There are several intrinsic factors at play. These are Job autonomy, Interesting work, Recognition, Flexible working hours, Achievement, Low stress levels and Leadership. These factors indicate the perceived usefulness that a person using the system will improve their actions and their performance will also increase.

Job autonomy: Autonomy and is defined as the freedom employees have to do their jobs as they see fit (Spector, 2006). Research has indicated that the greater the autonomy of employees the greater their intrinsic motivation (Robbins and Judge, 2009). According to Taylor, Bradley and Nguyen (2003), one of the variables that may be expected to influence job satisfaction is 'the degree of perceived autonomy that workers enjoy in the way they do their job'. The expected relationship is that more autonomy is associated with greater job satisfaction. Job autonomy can also influence an individual's intention towards the system usage, which will influence their behavioural change to use the system.

Interesting work: An interesting job will make an employee productive and challenged to continue performing at a higher standard. It is the responsibility of every manager to find new ways of incentivizing employees who are performing well by enlarging their scope of work (Jawahar and Hemmasi, 2006). The perceived ease of use can make an individual start believing that using a particular system is not complicated and does not need much effort and this will result in employees enjoying their work.

Recognition: A good company will take time to acknowledge and appreciate every individual effort in trying to achieve organisational goals set, especially when the employee goes beyond a call of duty (Field, 2008). Recognition plays an integral part on employee performances as it's a sign that their contributions towards the attainment of a set goal are recognized by the management of the company (Field, 2008).

Flexible working hours: Flexible hours makes employees happy (Hall, 2004). The company can make the office work environment more interesting by giving employees an option to work at home as well (Jawahar and Hemmasi, 2006).

Achievement: Individuals who believe that they can achieve anything they set their targets on, often accepts challenging tasks and put an extra effort to achieve those outcomes (Bergh and Geldenhuys, 2014).

Low stress levels: Employees who feel that their job does not correspond with their personal lives and feel that they are being pressured at work to perform at a certain level may become negative and will make mistakes which will ultimately reduce job satisfaction (Greenberg and Baron, 2003).

Leadership: According to Hirtz, Murray and Riordam (2007) effective leadership and employee job satisfaction are the two most fundamental aspects for any organisational success. Happy employees are able to work with a leader who motivates and guides them to better their performance (Cascio, 2005).

Extrinsic factors: According to Bergh and Geldenhuys (2014, 167), "Extrinsic motivation comprises external drivers which include things like situations, rewards, circumstances, or punishment, which result in obtaining external benefit". There are various extrinsic factors such as job security, working environment, job expectations, pay, job enrichment, job rotation, and fairness of treatment, promotional opportunities, and relationship with supervisors, relationship with co-workers, organisational support, personal characteristics and workplace integration.

Job security: Organisational instability leads to anxiety from employees (Cooper, 2006). Job security is defined as the probability that an individual will keep his job and income. A job with a high level of job security means that the person with the job will have a small chance of becoming unemployed (Robbins and Judge, 2009).

Working environment: Work environment plays a vital role since it influences job satisfaction, as employees are concerned with a comfortable physical work environment that will ultimately renders more positive level of job satisfaction (Robbins 2009).

Job expectations: The relationship between employee expectations of the job activities and the actual job requirements is an important factor to job satisfaction (Acker, 2011). Furthermore, employees experience role stress when their job demands are inconsistent with their job expectations (Acker, 2011).

Pay: Reward is defined as a payment often offered as an incentive for the accomplishment of a task (Marcus and Van Dam, 2007). Mount, Lies and Johnson (2006) are of the opinion that, when workers are paid well they feel valued by the organisation.

Job enrichment: This involves giving deserving employees an opportunity to perform tasks which are more complex and that carry a degree of responsibility and authority (Bergh and Geldenhuys, 2014). 
Job rotation: Job rotation allows employees to work on variety of jobs within the organisation. The advantage of having employees performing varies jobs is that they gain valuable skills and experience (Kiley, 2011).

Fairness of treatment: Organisational behaviour research has revealed that individuals who express high satisfaction in their jobs are likely to be more productive, have higher involvement and are less likely to resign than employees with less satisfaction (Gautam, et al, 2006).

Promotional opportunities: Opportunities for promotion can be used as an incentive tool by management to ensure that employees who perform at a higher level will be rewarded for their efforts in a long term (Blyton and Jenkins, 2007).

Relationship with supervisors: According to Hussami (2008), it was indicated that employees feel comfortable with a supervisor they can confide to and trust. If the supervisor does not trust them, or is abusive towards them, this will lead them to feel dejected in their work environment.

Relationship with co-workers: The company must ensure that there is a cordial, social relation in the work place. Every employee expects to be treated fairly by other workers (Luthans, 2005).

Organisational support: According to Robbins and Judge (2009), organisational support is what employees perceive and believe that the organisation values their contribution. Employees need regular access to management in order to voice their concerns with regard to any matters impacting on their livelihood.

Personal characteristics: Those who are communally oriented and gain satisfaction and fulfilment from helping others may be able to avoid job burnout better than those who report low communal orientations.

Workplace integration: Formal integration takes place when employees are taken through the company values, vision, mission, and policy manuals. The informal process takes place through office gossips and other staff interaction.

\subsection{Theories and Models of Job Satisfaction}

Job satisfaction is a very important attribute which is frequently measured by organisations. Employee satisfaction is an important issue for management and employees in any organisational setting (Rothmann and Cooper, 2008). Employees differ from each other in many ways. They have different abilities, personalities, values, and needs. These theories consider individual differences in terms of needs as particularly important for explaining what motivates people (Rainey, 2003). There are different job satisfaction theories or models:

Affect Theory: Edwin A. Locke's Range of Affect Theory (1976) is the most popular job satisfaction model. This theory determines that a person's job satisfaction can depend on two broad factors: expectations about what an employee wants in a particular job and what the employee is actually getting from his job (Ball, 2011). The theory further states that the narrower the gap between what the employee is expecting and the reality he is getting on the job gives an indication that there are more chances an individual will be satisfied in his job (Bergh and Geldenhuys, 2014).

Content Theories of Job Satisfaction: The content theory of job satisfaction focuses on identifying the needs, incentives and motives that drive people (Luthans, 2005). Individuals in the organisation have certain expectations, and creating an environment where these can be fulfilled, depends upon an individual's perception as to whether organisational environment suits their needs or not (Ray and Ranjan, 2011).

Maslow's Hierarchy of Needs: In the late 1970's Abraham Maslow's developed a hierarchy of needs theory. The model proposes that people's needs range from a basic to a high level and their needs are motivated in a hierarchical nature. These needs are present with every human being (Bergh and Geldenhuys, 2014).

Hertzberg's Two-Factor Theory: In the late 1950s Frederick Herzberg developed a theory of motivation which asserts that there are two factors which can satisfy and dissatisfy an employee at work and those factors are motivation and hygiene factors (Bergh and Geldenhuys, 2014). Herzberg is of the opinion that hygiene factors arise from a person's inner beliefs while the motivational factors relate to the person's ability to achieve and grow psychologically (Hellriegel, et al., 2009). Hygiene factors are those mostly found from the working environment that that if they are presented, do not necessarily mean that the work performance of an individual will improve (Kiley, 2011). Motivational factors include job promotions, bonuses, and public recognition of an individual performance (Hellriegal et al, 2009). The continuing relevance of Herzberg theory is that there must be some direct link between performance and reward, whether extrinsic as in recognition or intrinsic as in naturally enjoyable work, to motivate employees to perform and improve their job satisfaction (Karimi, 2008)

Motivator factors: According to Herzberg, motivator factors are aspects of the job and organisational contexts that creates a positive feeling among individual employees (Hellriegal et al. 2009). Motivation factors include but not limited to, employee achievements, increased responsibilities, challenging work, growth and development (Hellriegal et al. 2009). According to Kiley (2011), Employee participation in decision making gives them an opportunity to feel that they are part of an organisation and are considered as important factors in decision making process and planning. These motivator factors tend to be conditions that would satisfy higher level needs (Lane, 2007). 
Hygiene factors: Hygiene factors are considered the non-task characteristics of the work that creates dissatisfaction in a working environment (Hellriegalet et al.2009). Improving these factors may decrease job dissatisfaction and thus increasing of motivators. Inadequate hygiene factors may lead to dissatisfaction, but at the same time adequate hygiene factors do not necessarily lead to job satisfaction (Lane, 2007). Managers should be able to motivate all employees in the same way by ensuring the presence of both the hygiene and motivator factors (Walker, 2007). Hygiene factors include aspects of the working environment associated with the job and include factors such compensation and the level of an individual employee responsibilities. Other hygiene factors relates to an organisation as a whole and include company policies and administration, supervision, working conditions, interpersonal relations, money, status and security (Wall and Stephenson,2007). The fact that an organisation has a fair company policy pays its employees on time and provides employees with adequate resources to perform their tasks will not make employees happy (Bergh and Geldenhuys, 2014). Organisations cannot afford to ignore hygiene factors as employees will be generally unhappy and thus likely to seek other opportunities, while mediocre employees might stay on, and compromise the organisation's success (Walker, 2007).

Alderfer's ERG theory: In 1972 Clayton Alderfer proposed his ERG theory in order to address some of the limitations the Maslow theory presents (Kiley, 2012). The ERG theory presents three levels of needs as follows: Existence includes all material and physical desires needed for every human being to survive (Bergh and Geldenhuys, 2014).

Relatedness involves the need for individuals to have relationships in such a manner that, those thoughts and feelings are shared amongst each other (Hellriegal et al, 2009).

Growth relates to the need for individuals to be more productive, change their environmental set up and their characters (Daft and Marcic, 2011).

McClelland's needs theory: In the late 1967's David McClelland's developed a theory which holds that people have needs that are socially learnt through people's interactions with each other and even on people they held high as their role models (Daft and Marcic, 2011). This theory asserts those social contexts in which people live and work influence the learning of motivating needs and their strength which ultimately influence their behaviour in the society (Hellriegal et al, 2009). The three needs are as follows:

The need for affiliation motive - an individual desire to develop and main close ties with other mutually beneficial individuals. This motive urges people's willingness to work together in a team environment (Bergh and Geldenhuys, 2014)

The need for achievement motive - this is characterised by an individual desire to succeed in every competitive situations. People with higher expectations in life always sets their goals high and desires to achieve them as they tend to work hard at work (Bergh and Geldenhuys,2014).

The need for power motive - the desire to control and influence others at work or in the society. The power motive is expressed in two ways, namely the personalized power and the socialised power (Hellriegal et al, 2009). In personalized power, a person likes to exploit and manipulate others while the socialised power involves individuals using their power to solve organizational problems and assist the organisation to achieve its set goals (Hellriegal et al, 2009).

Dispositional Theory: This theory suggests that job satisfaction is closely related to people's personalities (Judge and Klinger, 2007). This approach also posits that an individual has a tendency towards a certain level of job satisfaction and those tendencies remains fairly constant and stable across the time (Barsade and Gibson, 2007). Judge and Klinger (2007) also argued that there are four core self-evaluations that determine one disposition towards a job satisfaction: self-esteem, general self-efficacy, locus of control and neuroticism. This theory also states that the higher the levels of self-esteem and general self-efficacy will lead to a higher job satisfaction (Judge and Klinger, 2007).

Expectancy Theory: This theory was developed by Victor Vroom in 1964, who asserts that job satisfaction is based on people's beliefs about the probability that their effort will lead to performance multiplied by the probability that performance leads to rewards and the value of perceived rewards (Kassin, 2006). This theory is based on the belief that the amount of effort exerted on a job depends on the expected return and may result in increased pleasure or decreased displeasure, and that people may perform their job and be satisfied if they believe that their efforts will be rewarded (Ball, 2011). The fundamental principle of expectancy theory is the understanding of individuals' goals and the linkages between effort and performance, performance and rewards, and rewards and individual goal satisfaction (Ball, 2011). This theory recognises that there is no universal principle that explains people's motivation and is regarded as a contingency model. Understanding what needs a person seeks to satisfy does not ensure that the individual perceives high performance as necessarily leading to the satisfaction of these needs (Feist and Feist, 2009).

Job Characteristics Model: In late 1976, J Richard Hackman and Greg Oldham developed a job characteristics theory model which describes that the task itself is key to employee motivation (Ball, 2011). Bergh and Theron (2009) define the job characteristics theory as the relationship between job characteristics and an individual 
response to a task. To perform any job, employees must have an ability required and willingness to perform such tasks. Managers must design jobs that motivate employees and satisfy them at work. The model asserts that the job should be designed to possess characteristics to enable conditions for high motivation, satisfaction and performance. Ball (2011) indicates that a boring and monotonous job stifles motivation to perform well, whereas a challenging job enhances motivation.

Equity Theory: According to Daft and Marcic (2011), fairness is the cornerstone of this theory which was developed by J. Stacy Adams. This theory holds that employees hold a certain belief that they ought to receive the same or similar rewards as people who are performing same or similar tasks in the same or similar circumstances. Equity theory suggests that individuals assign weights to various inputs and outcomes according to their own perception of relative importance. Inputs are what an individual contributes to an exchange, while outcomes represent what an individual obtains from an exchange (Hellriegalet et al.2009). Employees often compare rewards they receive in the form of recognition, status, benefits, money, promotion and allocation of job tasks with the amount of effort they have expended in performing such task (Ball, 2011). This implies that, if employees perceive that their treatment is less favourable than that of others with whom they compare themselves, they are likely to be less motivated to perform better (Daft and Marcic, 2011).

Discrepancy Theory: This theory suggests that an individual's job satisfaction emanates from what they feel is relevant and important for them in a working environment rather than the fulfilment or unfulfilment of their needs. Job satisfaction is determined by the extent to which an individual receives what he or she expects from a job (Zaidi, 2009). Discrepancy theory also explains that if achievement of the obligations is obtained then the reward can be praise, approval, or love (Robbins, Odendaal and Roodt, 2003).

Quality of work life (QWL) also known as Theory Z: QWL is an approach to management and motivation of organisational employees that is founded in the Japanese historical and cultural experiences (Montana and Charnov, 2008). The QWL goal is to create a commitment from an organisational perspective, a friendly or unfriendly working environment for all its employees (DCenzo and Robbin, 2004).

This model calls for the active participation of everyone within the organisation. Price (2007) states that empowering frontline employees and emphasis on team work creates and harness employee's true potential which then leads to high quality performance and success for the organisation.

Goal setting theory: This theory was developed by Edwin Locke in the late 1960's and is primarily based on the idea that an individual behaviour is regulated by his intentions and that managers can actually directs the performance of each and every individual within the company by assigning specific, difficult goals which employees accepts and commits themselves to attaining such goals (Latham, 2007). Shajahan and Shajahan (2004) assert that intentions can be a major motivation and satisfaction source. Goals should be mutually acceptable to the manager and an employee through consultations with an individual concern.

\subsection{Measuring job satisfaction}

Usually job satisfaction is measured by using general scientific research methods such as the questionnaires and can be implemented both individually and sometimes in groups. The majority of job satisfaction measures are self-reports and based on multi-item scales. Several measures have been developed over the years, although they vary in terms of how carefully and distinctively they are conceptualized with respect to affective or cognitive job satisfaction. They also vary in terms of the extent and rigour of their psychometric validation. Some of the most commonly used techniques for measuring job satisfaction include: The Minnesota satisfaction questionnaire, job description index, the brief index of affective job satisfaction, overall job satisfaction, global job satisfaction, job satisfaction relative to expectations, job in general scale, job satisfaction survey, job satisfaction index, job diagnostic survey and career satisfaction.

\subsection{Consequences of job satisfaction/ dissatisfaction}

The effects of employee job dissatisfaction can cause huge detriment to an organisational performance. Low morale amongst employees can lead to strikes, stress and absenteeism. Managers must be constantly looking for any signs of low morale and job dissatisfaction amongst employees and ensure that they take corrective measures to address the problem as soon as possible (Miller and Rosse,2002).

Organisational culture and climate: Strong organisational culture and climate are the most determinants of employee satisfaction and dissatisfaction. Where an organisation has an open culture that allows communication to flow easily and allows employees to be part of decision making process, this can lead to employee satisfaction but when it is not available, then it can lead to job dissatisfaction (Luthans, 2005).

Employee absenteeism: According to Cohen and Golan (2007), "absenteeism is exhibited when an employee fails to report for work, for an extended period of time, or for an excessive number of days without the authority and permission from his manager". Less satisfied workers are more likely to be absent at work than dissatisfied employees (Nelson and Quick, 2008). 
Organisational commitment: According to Farndale, van Ruiten, Kelliher and Hope-Hailey (2011), it was indicated that when employee perceive themselves as having an impact on organisational decision making process, they tend to show high levels of organisational commitment.

Employee turnover: According to Frank, Finnegan and Taylor (2004), losing an employee that is productive and vital in maintaining structures and smooth workflow can be very detrimental for a company.

Union activity: The evidence for dissatisfaction is a major cause of unionisation. In addition, the employees feel that individually they are unable to influence changes that would result in the alimentation, of those factors that cause job dissatisfaction. Lower level of union activities is related to the level of job dissatisfaction and lower level of job dissatisfaction may result in grievances while higher level of job dissatisfaction may result in employee strike (Ayeni and Popoola, 2007).

Productivity and performance: Christen, Cryler and Soberman (2005), note that a positive effect of job performance on job satisfaction also has important implications for a firm that wants to motivate and retain talented employees.

Withdrawal behaviours: When employees are disillusioned, they tend to leave the employment of the company as recourse (Robbins, 2007). Employees can respond to their dissatisfaction in a number of ways:

- Exit, they can leave the company and find another employment with another organisation which suits their needs.

- $\quad$ Voice, they become vocal about things that need to be changed.

- Neglect, they become less loyal and come to work when they want.

Any organisation that needs to successfully implement the new system needs to develop strategies that will involve the improvement of usefulness and ease of use of the system. Usefulness of the system can be achieved by ensuring that communications lines between managers and employees are clear and that the system that has been design is task oriented and training is offered to all users. The perceived ease of use can be achieved by having computer interface built in so as to allow users ease of access. The literature review has shown that it is critical for the user to accept the system and continue to use the system in order to fully understand enjoy using the system. These factors tend to show that employees love their job if they get what they believe is an important attribute of a good job. Job satisfaction represents one of the most complex areas facing today's managers when it comes to managing their employees. Many studies have demonstrated an unusually large impact on the job satisfaction on the motivation of workers, while the level of motivation has an impact on productivity, and hence also on performance of business organisations. There is a considerable impact of the employee's perceptions for the nature of his work and the level of overall job satisfaction. Financial compensation has a great impact on the overall job satisfaction of employees.

\section{Research Methodology}

Research design is a critical framework of the study which contains elements of the study to be used as a guide to collecting data and conducting the data analysis (Wiid and Diggines, 2013). Research design comprises various decisions to be taken prior to undertaking the study and provides a plan on how to execute that research project (Wiid and Diggines, 2013). The research study used a case research approach. This research was explorative in nature as it intends to tackle new problems on which little or no previous research has been done (Brown, 2006:p.43). According to (Babbie, 2001:304)), content analysis can be defined as "the study of the recorded human communications". Content analysis is a methodology used for determining the content of what has been written, recorded or published information (Babbie, 2001:309). This methodology allows an inference to be drawn about the characteristics and meaning of the recorded material obtained through interviews (Babbie, 2001).

\subsection{Population}

According to Brynard and Hanekom (2005:43), a population does not necessarily mean the population of the country but it includes all objects, participants, phenomena and cases that the research intends to study. Wellman and Kruger (2005:53), state that the "population is the study of object and consists of individuals, groups, organisations, human products and events or the conditions to which they are exposed". In this research study, the population consisted of participants who were directly involved in the telemarketing of products for the company as well as the design team of the new system.

\subsection{Sampling}

According to Steyn, Smit, Du Toit and Strasheim (2007:16), a sample is defined as "any subset of the population". O'Leary (2004:103) is of the opinion that sampling involves a process that is strategic, and, on numerous occasions, involves mathematical calculations in order to get a sample that best represents a larger population. The non-probability sampling method has, as its objective, to select a sample that captures a wide 
range of facets (Wiid and Diggines, 2013). It is a sampling technique which gathers samples in a manner that does not guarantee anyone in the population equal chances of being selected (De Vos, Strydom, Fouché and Delport, 2011). According to De Vos, et al. (2010), a simple random sampling is the easiest of the sampling method as it gives every member of a population an equal and independent chance of being selected to be part of the research study. In this research study, a total of twelve individuals were selected to be included in the study and interviews were conducted with them using the simple random sampling method as there is no bias in the selection process. The first group had consisted of selected members of the design team who answered questions regarding the intended use and usefulness of the eBiz system. The second group consisted of selected members of the users in a selected eBiz environment. The first group was made up Project Manager, Business Analysts, Systems Analysts, Architects, System Engineers Integrators and Consultants. Interviews took place with at least one of each category selected using simple random sampling of six from the group of 30 . Therefore six interviews were conducted in order to determine how the process was intended to work and what possible pitfalls were envisaged with regards to employee use. The second groups consisted of users of the new system at various levels of management and were interviewed to gauge their perceived job satisfaction with regards to the new system and had exposure to the new system. They second group answered questions with regards to the usefulness and ease of use of the system and indicated their perceived satisfaction with their jobs based on the system change.

\subsection{Pilot study}

A pilot study is conducted when a new instrument is developed in order to determine whether the survey instrument is unambiguous and covers all aspects of the research topic (De Vos, et al. 2010). The objective of the pilot study was to test and identify any ambiguities within the survey instrument used. Two members from each group were selected purposively $\mathrm{f}$ and participated in the pilot study. These members confirmed that the questions were clear and easy to follow. The two members who participated in the pilot study were excluded from the full study.

\subsection{Data collection}

Interviews were conducted with randomly selected members of the design team and the users. An open-ended interview, as a data collection method, allows people to express what they think in their own words without any hindrances or fear (McLeod, 2014). Flick (2006:6), is of the opinion that the purpose of interviews "is to reveal existing knowledge in a way that can be expressed in the form of answers and so becomes accessible to interpretations". Rich qualitative data is obtained, as open-ended questions allow the respondent to elaborate on their answers (McLeod, 2014). Open-ended questions were used with all individuals selected to participate in the research study. Participants were asked to answer questions without any fear of being victimised. Furthermore, participants were asked if they have any objections in having their interviews recorded. Telephonic interviews were conducted with any participant who will not be available at a set appointed time and date. The interviews conducted with participants lasted not less than 45 minutes on average.

\subsection{Data analysis}

According to Steyn, Smith, Du Toit and Strasheim (2007), data analysis involves the description of the data collected, categorising and interpreting the results of data collected. Zikmund (2003) is of the opinion that analysis is the application of reasoning in order to gain an understanding of the data collected. The interview data were analysed using content analysis in order to collate the expressions and opinions of the interviewees. This was done in order to search for patterns and provide a deep and information-rich understanding of the research concepts. The process followed in the content analysis was the preparation of the data for analysis. This was done in the form of transcribing all participants' interview responses into text and read through all interview transcription to ensure that all questions were answered and brief notes were done where similarities in responses to questions were identified.

\subsection{Methods taken to ensure data reliability}

Reliability is synonymous with stability and does not necessarily mean that it is valid (Wiid and Diggines, 2013). De Vos et al. (2005) refer to "transferability, reliability, conformability and authenticity" as cornerstones to establishing significant research study results. Every systematic inquiry into the human condition must address these issues.

Credibility: The main objective of the research study is to ensure that data gathered clearly demonstrate that the study was conducted in a trustworthy manner (Wiid and Diggines, 2013). Participants on this study were people in the employ of the company who had one or more years of uninterrupted service. 
Transferability: This refers to an extent to which the results findings of one research study can be used or applied in other situations (De Vos et al. 2005). The results of this research study can be used in other transformation situations.

Dependability: This means that in trying to address the issue of reliability, it is important to ensure that, if the study was to be repeated in the same context, methods and with same participants, similar results should be obtained (Saunders, Mark, Lewis and Thornhill, 2000). The results of the research study were based on participants honest responses to questions raised.

Conformability: It is important that the researcher takes measurable steps to ensure that the research study findings are based on information obtained from participants and not on his preferences (Saunders, et al., 2000). This will ensure the objectivity of the study. The findings on this research study were based on participant's account of the events at the company.

Authenticity: This process was taken to ensure that data captured represents the participant's version of events. Steps of thematic content analysis were followed. Records of questionnaires were kept for reference. (De Vos et al. (2005).

Reliability: This is the method used to collect and capture data to ensure that the data collected is reliable and that the researcher did not alter anything in the process of capturing information collected from the participants. A reliable method used to gather data gives consistent results in different applications (Wiid and Diggines, 2013). The research participant's responses to the questions were not tampered with to ensure that it was the true version of the participant responses.

\subsection{Methods taken to ensure data validity}

Wiid and Diggines (2013) define data validity as the degree to which a construct measures what it is designed to measure. In actual fact, validity measures what the research study intends to achieve. According to Anderson (2004), any person who needs to undertake a research study should bear in mind that the study will not produce findings which can be measured as hundred percent reliable and valid.

Face validity: The participants to the research study had an opportunity to read questions and ask where necessary.

Content validity: The pilot study conducted prior to broader administration of interviews helped to ensure that the interview questions were understood and not cumbersome.

Criterion validity: The interview questions set was in response to the research study objectives.

Construct validity: The characteristic of construct validity is its ability to discriminate unnecessary measures (Polit and Beck, 2012).

Concurrent validity: The participants were advised to relax and answer questions honestly without any fear or favour.

\subsection{Ethical considerations}

A moral issue is not a matter of choice but a necessity. Any unethical behaviour will bring the research study into disrepute and its credibility will be dented (Bless et al. 2007:140).

Informed consent: An official letter bearing the college letterhead was used to address the issue of informed consent those who were invited to participate in the research study.

Anonymity: The participants to the research study were not known to the researcher and their participation to the study was voluntary.

Do not harm respondents. The research study minimized potential harm by ensuring that respondents were afforded the chance to set interview times and dates. This assisted in minimizing disruptions at work. Participants to the research study rights to privacy were guaranteed prior to interviews taking place.

Confidentiality. All data collected from the respondents was held in a secured place. This was done to ensure that no one who is not party to the study will have access to interview responses from any participants.

\subsection{Limitations}

The collection of data was a challenge as most of the employees selected to be part of the focus group to be interviewed were either already on vacation or trying to chase their targets for the month which became a tedious exercise to follow up and increase the response rate. Time taken for interviews was also a factor as most of the participants in the research study were using public transport and their interviews had to be done late after work and in some instances transport fares had to be provided in order to complete the project.

\section{Results}

Participants were asked questions based on their knowledge and expertise on how the new system operates and their perception in order to gauge the level of satisfaction. Open ended questions were used for all participants. There were several factors which had a negative effect on the number of participants chosen and 
the time it took to finalise all interviews during a specified period: Firstly, the response rate for electronic survey questionnaires is reported as low in research studies. This was compounded by results from the pilot questionnaire which indicated that the survey was in some instances being filtered by anti-virus software and delivered into people's junk mail with the effect that it could be missed by the prospective recipient and as a result deny them an opportunity to be part of the research study. Secondly, there were time constraints for the data collection due to the limited time available for the research. Thirdly, the data collection period was at the year end and over a time period when many staff was preparing to go on vacation or were already on leave while others rose an issue of meeting their deadlines on time which became near impossible to get hold of them to attend the interview as scheduled. $58 \%$ of participants selected were males and $48 \%$ represents females on the sample selected. The work experience was determined to gauge respondents' ability to understand the processes and procedures followed when the new electronic business system was implemented. The majority of participants have been with the organisation for more than 10 years which gives an indication that they understand the system implemented well. Many of the people have degrees and followed by those with either an honours or a BTech.

\subsection{The use of the electronic business system in allowing changes}

The participants' responses to this question were that the system allows them to make changes during the use. They have indicated that if an error, for whatever reason has occurred during the imputation of data, a pop-up message will be displayed on screen alerting the user to make the necessary changes before proceeding to the next field. Generally, the responses from participants was that the system has made their work performance much higher than they would ordinarily be if they were still using the traditional old methods of filling myriad of forms when dealing with a potential client and have back to back meetings with a client until a policy document has been approved and sent to that client but with an electronic business system introduced, everything is done on real time and clients are able to access their information online as well without any delays. The new system also brought a new way of conducting business for consultants as they were now able to lodge claims online and a client can be able to track the movement on is claim online as well. Some participants indicated that the new system, is so useful for their performance and that their production in terms of the number of new business they close with clients had increased as the use of forms had been minimized to a certain level. The participants further indicated that the new system has brought a new way of communicating with their clients as well as their own colleagues. The system has a capacity to record and store conversations they have with clients for future reference in trying to resolve any disputes where a client indicates that they did not request any changes made to their policies. The participants also made mention of the fact that the system keeps tabs of what employee is doing on a daily basis in terms of their overall performance using the new electronic business system. The new system has brought a new dimension even for managers as they no longer have to go through a myriad of forms in order to resolve a query. They only have to log onto the system and retrieve such a document in real time processing. The participants responded positively indicating that their role at the company is like that of a business owner as they are responsible for their own diary and setting of appointments with potential clients and they feel that they are highly independent when performing their tasks of being a financial advisor to a client. Most of the participants have indicated that because they are not office bound, the new electronic business systems come handy as it can be operated anywhere anytime of the day without any restrictions. The good thing about the system is that it can also be operated on an android system even at home. The speed the system takes to process documents also gave participants an opportunity to be rewarded greatly at the end of the month and one can also go the extra mile to achieve greater than the given targets on a monthly basis. The system also allows us as users to be well informed of how our performance for that particular month is going and this can give an indication as to whether the employee is lagging behind or still well ahead of time in terms of their performance. The participants expressed their gratitude towards the decision management has taken to implement the system as their production has increased with the implementation of the new electronic business system.

\subsection{The ease of use of the electronic business system}

The responses were that, indeed the job would have been difficult to perform if the new system was not implemented. There were indications that the implementation of the new system has shown that the production has been steadfastly growing amongst the employees of the organisation. According to participants, the new system also helps them to compile financial planning for clients much quicker than they would ordinarily do if they were still using the old traditional methods of using application forms. Participants also indicated that the system was not only designed to make their work more easily and speedily but the system also brought an added advantage in their work environment and also places the organisation mandate to deliver to clients policy documents on time unlike when the system was not in operation. Participants further mentioned that, when an error occurred during the imputation of data, the system would immediately inform the user that an error has 
occurred and needs to be rectified unlike if a form is used to capture the client information, if the error is found to have been committed, a consultant has to go back to a client to request the required information and make that correction which is time consuming and costly. It has been reported that since the implementation of the new system, the organisation profit margin has been growing steadily and they are still the leaders in the insurance industry owing largely to the system they have implemented. The participants indicated that the communication from management to employees had improved largely due to the new system that was implemented. The management of the organisation were now able to share new products to be offered and any other valuable information to the entire staff complement speedily even before a training for new products to be offered by the organisation can be rolled out, employees are able to view them only and start perusing the benefits the new product will offer ands such they can start planning on how to go about convincing their current and prospective clients on the new product and that was made possible by the electronic business system which was implemented for use by all employees. According to participants, the system has made their jobs much easier by the implementation of the system which is ease to operate and be able to produce documents on time when the client needs such information. The system also had a backup of the tasks already performed for the month in order to go back and check if all the policies have been processed or not. Participants also mentioned that the implementation of the new system has reduced the error rate margin drastically as the system is now able to alert you when an error has occurred and such can be corrected immediately without any delay. The productivity of employees can be measured quickly by the management at any given time using the new system. The participants further mentioned that the slack time had been cut off. Participants have also mentioned that the implementation of the new system has brought about the end to the use of forms when dealing with clients as information is readily available electronically and more work gets done than before where they used to work on forms to fill in the client details. Participants have responded by saying that the job they do of being a financial advisor has a huge impact on any ordinary person as they seek to be part of solving individuals financial problems by giving them proper and sound financial advise on how best to manage their finances all the times. They have indicated that it is their nature to keep contacts with all their old and prospective clients and continuously seek new prospective clients. Participants have also indicated that the type of information and professional behaviour they must display at all costs whether they are with clients or not bodes well for the organisation as it can serve as a good rapport to other would be clients of the company. The participants have emphasized that the time it takes for them to respond to a client query positively also bodes well for the company and client as well. The majority of participants have shown that their work has a positive contribution to the clients they represent and strongly believe that their influence is felt in and outside of the organisation.

\subsection{The challenges experienced with the use of the electronic business system}

The participants have responded to this question by mentioning that they normally have weekly meetings and trainings on the use of the electronic business system where new developments on the system are discussed and where necessary system updates are affected based on the discussions they will have amongst themselves based on the experience they had on the use of the electronic business system. Participants also indicated that the trainings and meetings they held assist them to keep abreast of new developments and products to be launched and offered by the organisation. They also indicated that the organisation conducts internal surveys on the use and experience people had with the use of the electronic business system and based on the results of the internal survey changes are also suggested to make the system more and more ease to use. The upgrade of the system is done automatically as soon as they are available. The results of such surveys are also shared amongst all employees to see how people really perceive the new system implemented. Supervisors and managers also send staff on refresher courses about the electronic business system use at the organisation academy if there is a need for such a refresher course if a participant is finding it difficult to use the new system at any given time.

\subsection{The extent of employee satisfaction after implementation of the electronic business system}

The response from participants has shown that their job requires them to interact with people of different walks of life in order for them to close new business for themselves as employees and for the organisation to achieve their set goals for the year more often. It has been indicated that the high frequency and importance of keeping contacts with clients outside of the organisation must be great at all times. Participants have also indicated that they spend great deal of time discussing and explaining new products being offered by the company to people as part of trying to convince them to sign up for a new product which will ultimately benefits them in the future. Another point mentioned was that it is important to treat all people they interact with in a professional manner in order for them to go and do a word of mouth selling of the products they have just presented to them to other people and refer them back to a consultant who have helped them to take that decision for further explanations on the benefit such product offers to a client. The participants also mentioned that, because they are supposed to interact with people outside of the organisation on a daily basis, it is imperative for them to be at their behaviours and treat people with the respect they deserve all the times. 
Participants also mentioned that they have never been subjected to any disciplinary procedures as they always conduct themselves in a proper manner. It was also mentioned that, the company as an organisation also participates in community social investments programs and as a result, employees are urged to go and motivate the less fortunate communities about what the organisation can help them to access funds for their non-profit organisations to run various programs as a community and that requires employees to conduct themselves in a professional way. Participants say they do get valuable support from their supervisors and managers alike as they are working in a target driven environment where any slip ups can cause the organisation not to reach the set target which has an implication on their income. It was also mentioned that supervisors also provides actionable suggestions where progress by the employee is lagging behind the rest of the team in order to improve the performance. Participants also mentioned that the amount of work they generate monthly is as a result of the support and assistance given by their supervisors in order to attain more results for the organisation. It was indicated that because managers know the staff under them, it is easy to be able to assist them based on their strength and weakness already known. The electronic business system implemented has also greatly assisted in making sure that performance of employees is monitored anytime in order to improve where necessary. The supervisor also suggests training interventions where necessary and the period of training is something that is agreed upon between the two parties involved.

\subsection{Perceived usefulness of the electronic business system}

The respondents answers for the majority of them was that they do provide training to the users of the system but emphasis was made that the training they offer is mostly refresher courses to those who are really experiencing challenges when using the system. The participants also stated that they are on standby to assist where there are problems with the system within the office environment. The other responsibilities which participants made mention of was regard to sensitizing the employees on the security they need to adhere to when using the electronic business system and to ensure that no security of the organisation can be compromised in anyway whatsoever. Participants advised that they do consult the user manual as the information technology evolves and it is always advisable for one to always keep them abreast on the new development the industry has introduced so that they can work better with the technology. Participants also indicated that it is of critical importance for them to continue attending refresher course on the electronic business system so that they can become better technician who will be able to assist employees of the organisation when a need arises and therefore manuals will be able to be consulted on. The participants also mentioned that the manuals can be used by the users of the system if they need to have a better understanding on the use of the system. The organisation also has a training academy where some courses on the systems are provided in order for the team to be better technicians but they also emphasized the fact that they become more proficient on the use of the system that manuals will not be needed every day. The system has been designed to offer an ease access to the highest technology and be user friendly to the users and as a result manuals are consulted on those extreme cases. The participants indicated that there is a serious need for any organisation to try and integrate their functions and business processes to improve its responsiveness to issues related to its employees and clients alike and it is important for the company to ensure that there is free flow of information and transparency in terms of how the business operates. Participants have indicated that the implementation of the new system has brought an element of growth in that they are able to do more work than they would ordinarily do when using other systems. The participants also mentioned that the system which an organisation has implemented for use by employees has actually managed to reduce costs of printing myriad of forms to be distributed to various offices. They also indicated that the system allows the design team to perform data conversions and application communications very quickly to the users. There was general perception that the system implemented by the organisation has enhanced their personal growth and productivity has grown up. Business across the world is changing on a daily basis to focus on the digital world and as a result for an organisation such as the company, it was a great move for them to implement and install new integrated systems which allow it stay flexible to changes in the insurance industry and to react to any changes that they might be facing promptly. Participants have mentioned that the system has allowed the organisation to stay competitive against their rivals in the insurance industry. The participants' response to the question was that, the system was designed to ensure that the competitive advantage the organisation enjoys over its rivals is maintained by ensuring that we deliver to our clients more benefits at a lower cost by ensuring that consultants are able to make changes to the system when working to a certain document. The participants also mentioned that the system updated itself regularly to ensure that employees have up to date information necessary to carry out their tasks. The participants also mentioned that the system is easy to use and productivity has grown steadily since the implementation of the electronic business system and there is an improved workforce productivity brought about by the implementation of the new system as employees are now able to view and locate information relevant to perform their task much quicker. The system is easy to use and friendly as it has ability to inform 
you on time of any updates that needs to be effected on the electronic business system and you are always up to date with any new developments that are necessary for the smooth running of the system.

\subsection{The perceived ease of use of the electronic business system}

The question needed to find the reasoning behind the intention the organisation had when they decided to implement the new system for use by its employees. Participants have indicated that the life insurance business in South Africa was under immense pressure at the time the new system was being configured and planned. The intention was for the organisation to go digital as the insurance industry was changing and the old ways of doing business of filling manual forms to capture clients information was now outdated and as a result the organisation has to come up with a system that will give its employees access to various products being offered and tools to use to capture clients information once a decision has been made by the client and as a result the organisation came up with the electronic business system which will assist employees to capture information about a client online and the results being made available immediately. Participants have also indicated that any poorly integrated electronic business system can create costly inefficiencies and as a result the organisation wanted a system that will ensure that there is a faster and quicker way of disseminating information to clients and employees was in place. The participants have also mentioned that the electronic business system also allows staff to view documents online much quicker and faster. The system also provides sophisticated security and auditing capabilities to ensure that the organisation complies with government stringent financial services regulations by making sure that if there is any form that needs to be filled in for compliance purposes, the system will send the notification on time for action to be taken. Participants mentioned that data security is of critical importance to Sanlam as they have sensitive information on their database which, if fallen on wrong hands of hackers, it can be catastrophic for an organisation as a whole which will have a financial impact on the organisation as they might be sued for information illegally accessed by hackers. Participants have also indicated that they interact with the system on a daily basis without fail and their productivity has grown up as a result of using the electronic business system and there are better controls and monitoring to ensure that the system is not attacked by cyber terrorists. Participants indicated that because the new system has a program which automatically updates it when there is a need. The participants also mentioned that the system has really assisted them to perform more tasks than they would normally do which is an indication that the participants will continue to use the system. They also indicated that as the complexity of conducting business online in today's world, the electronic business system ensures that as an organisation it strives to be the best in the field by making sure that they continue to deliver the best service to their clients by continuing to use the system. The system also records and reports to management on any business flowing to the organisation every time.

\subsection{The challenges experienced with the electronic business system}

The participants indicated that when the system was on the design phase, the users of the system were the determining factor in ensuring that the system to be implemented must be ease to use and friendly without too many processes to follow when accessing it. The design team also ensures that training is provided for those who are not quick enough to be able to use the system. The participants have also indicated that the introduction of the electronic business system has redefined the way the organisation conducts its business. The organisation has phased out the use of myriad paper based forms and now prefers the online use of forms to capture client's information in real time. The participant's advised that the system is not rigid or inflexible as it allows changes to be made when the user is operating it at any given time. The system will give an error message asking the user to make the necessary changes which is an indication that the system is not rigid neither inflexible. The participants also mentioned that the way the system was configured it is easy to use and makes the life of users much easier. The participants also indicated that there are ongoing systems improvements to ensure that the organisation stays relevant. The system has also managed to streamline the internal communication within as people are able to get information and access documents relevant for their line of jobs much quicker and easier without being bogged down by unnecessary processes. The participants also indicated that the organisation has been able to use the system to attract and keep new clients who have become champions of interacting with other would be potential clients about the experiences they had and time spent with a consultants on the electronic business system. The other issue participants raised was with regard to the people resisting to use the electronic business system and as a result some are trying not to cooperate or attend the training sessions offered to them. Training also takes time to conduct and this might pose a question of speed to release information to clients on time. The implementation of the system had also seen some people who perceive that the system is too complex or impractical to us to have resistance with the use of the electronic business system. The other challenge the organisation is facing with regard to the electronic business system is that of ensuring clients claims are processed on time without any delay. 


\subsection{The extent of satisfaction with the electronic business system}

The participants indicated that their role was on the installation of the security software necessary to ensure that the company assets and information from clients is safeguarded against hackers and cyber-attacks. Respondents have also indicated that they have also installed system monitors to ensure that any virus that is planned to attack the organisation is detected on time and prevented from installing itself into the electronic business system. Participants also mentioned that they do provide training for users of the electronic business system when there is a need.

\section{Findings}

The findings of the research study indicate that, for any organisation that needs to be in the forefront in this cut-throat competitive and rapidly changing business environment, it is important for the organisation to ensure that employees are satisfied and operating at a level at which the organisation can be able to fend any competition they might be facing or likely to face. Employees in organisation tend to do well when they can be able to see that there is a commitment from the management to ensure that they are rewarded and treated fairly at all times, their actions can be able to inspire employees to give their all in order to achieve the organisation set objectives. The organisation must, in conjunction with all users of the system must facilitate different types of trainings to be offered throughout the organisation in order for all to understand that the electronic business system is there to help and assist them to improve their knowledge base and organisational performance. The research findings also indicate that after the implementation of the electronic business system, there were increased employee satisfaction and performance has increased as well. Furthermore, since the implementation of the electronic business system, there has been an increase in employee productivity. Continuous trainings and dedication from all employees of the organisation is critical in the realisation of the organisation goal. The organisation has to continue updating the system to bring necessary improvements on the current system. Team work should also be emphasised to ensure that employees using the electronic business system continue to work together and share ideas in order to improve the system where necessary and ensure that there is dissemination of information from top to bottom. The organisation, due to its business nature should strive to guard against customer data which, if not safely guarded can become extremely valuable in the hands of criminals and competitors alike. The customer data obtained through the day to day business operation of the organisation business could potentially be sold and this might have a significant impact on the brand of the company and their profits. The electronic business system implemented should have security controls enough to thwart any attempts at gaining entry to the system unauthorised be denied access. It must be borne in mind that theft of customer information is an expensive recovery process and the brand of organisation gets tainted. No one wants to associate themselves with companies with lax controls. The organisation should strive to have all their internal staff being vetted in order to avoid employing people with control deficiencies who cannot be trusted with company valuable asset. The organisation must strive to maintain that all access pins to the system and fool proof and segregation of duties is maintained at all times. Access to the system should only be granted to those who can provide an authentic proof that they are allowed to access the system. Access to the system should be denied after three unsuccessful password attempts. Timeout operation should also apply if the user log onto the system and is no longer active on the system for a certain period of time and the system should prompt the user to log onto the system again to ensure that it is the same user operating the system. It is further recommended that for an organisation to have a very committed and satisfied workforce, it is important that the governance system in place should afford the decentralisation of powers which will ultimately give empowerment to the employees in information sharing and decision making process. If an organisation can afford that to its employees, loyalty to the organisation will then be sustained and members of the organisation will obviously start giving maximum output so that an organisation can be able to achieve its set objectives as determined by the strategic goals the organisation would want to achieve. As an organisation, careful consideration should be given to the intrinsic and extrinsic job satisfaction factors so that employees will be able to show their commitment and positive behaviours towards the organisation which ultimately assists in the attainment of the set goals. It is also important for the organisation management to ensure that if there are any grievances by employees, they are speedily attended to in order to avoid the disruption of the operations by disgruntled employees. It is recommended that the organisation management must create an enabling working environment that will have employees who are willing to go the extra mile in order to achieve its objectives. The study further recommends that the organisation must continuously rollout trainings in order to equip employees more on the use of the electronic business system implemented. The study further indicates that employees are motivated to play a crucial role if they are rewarded and the implementation of the electronic business has indicated that employees are striving to work extra in order to be rewarded. It is further recommended that the organisation should strive to provide employees with continued training on the use of the electronic business system so that they are all performing at a level where there is minimal resistance to use the system as a tool to 
enhance one productivity. The system should not be seen as a burden but a helping tool to perform one duty and that can only be achieved if all employees are trained continuously.

\subsection{Further research}

The following recommendations are suggested for further research to be undertaken in:

- It is recommended that further research be conducted in order to examine the criteria management can use to gauge correctly whether the system is achieving the intended purpose it was brought into the organisation for.

- It is further recommended that graphics and unnecessary animations should be kept minimal in order for the system to be user friendly. Animations slow down the system speed and this can lead to users of the system resistance to use the system.

- Designers of the system should consider displaying only relevant details on the system website so that there is an efficient management of the technology. This would lead to increase in the perceived ease of use and usefulness of the system.

- Further research has to be conducted on the effect of implementing the electronic business system without adequate training to the users and implementers of the system. Strategies to manage conflicts diverse cultures within the organisation during the transitional period should be investigated.

\section{Conclusion}

The study has concluded that, in order for the selected organisation to gain competitive advantage and adapt to the dramatic changing environment, it is important that the organisation must achieve management efficiency by increasing employee satisfaction. The study has also concluded that during the implementation of the system, major improvements became visible in that employees were now operating higher than they were before the implementation of the new system and it is safe to say that the changes brought by management with regard to the implementation of the new system had an impact on employees productivity and the organisation profit as they were steadily growing. The organisation must continue to provide employees with necessary trainings in order for them to achieve company set goals and not be demoralised. The organisation should continue to empower employees to embrace the new system implemented for it to be a success. Although the outcomes are specific to the selected organisation and the choice of BPR implementation, the study outcomes may apply to similar entities faced with challenges of integration of systems to allow for ease of access of just in time information while maintaining high levels of job satisfaction.

\section{References}

[1]. Carter, J. (2011). Career progression is the key to retention. Human Capital Magazine, Canada.

[2]. Robbins, S.P. (2004). Organisational Behavior 8th Edition. Upper Saddle River, N.J. Prentice Hall

[3]. Trkman, P. (2010). The critical success factors of business process management. International Journal of Information Management, 30(2), 125-134.http://dx.doi.org/10.1016/j.ijinfomgt.2009.07.003.

[4]. Ozcelik, Y. (2010). Do business process reengineering projects payoff? Evidence from the United States. International Journal of Project Management, Vol.28, No.1, pp7-13.http://dx.doi.org/10.1016/j.ijproman.2009.03.004

[5]. Kabir, M.M., (2011). Factors affecting employee job satisfaction of pharmaceutical sector. Australian Journal of Business and Management Research, Vol.11, No.4.

[6]. Robbins, S.P., and Judge, T.A. (2009).Organisation Behavior (13th ed.). Upper Saddle River, New Jersey: Pearson Prentice Hall.

[7]. Dessler, A.E. (2010).A Determination of the cloud feedback from climate variations over the past decade. Science Vol.330, pp $1523-1527$.

[8]. Diaz-Serrano, L. \& Cabral Vieira, J. A. (2005).Low pay, higher pay and job satisfaction within the European Union. Available at http://ideas.repec.org/p/iza/izapds/dp 1558.html. (Accessed on 12 November 2014).

[9]. Okoye, A.U. (2011). Attitudes of Primary School Teachers Toward Introduction of Career Guidance in Primary Schools. A journal that cuts all behavioural issues. Vol.3 (No.2).

[10]. McShane, S.L., and Von Glinow, M.A. (2005).Foundations of employee motivation. Accessed 14 December 2014,http://highered.mcgraw-hill.com.

[11]. Statt, D. (2004).The Routledge Dictionary of Business Management.3rd Edition. Routledge Publishing, Detroit, p.78

[12]. Armstrong, M. (2006). A handbook of Human Resource Management Practice, 10th Edition, Kogan Page Publishing, London.

[13]. Spector, P. E. (2006). Industrial and organisational psychology: Research and practice. Australia: John Wiley and Sons.

[14]. Blyton, P. and Jenkins, J. (2007). Key concepts in work: Los Angeles, California; London: Sage.

[15]. Mohapatra, S. (2013).The need for BPR and its history.Business Reengineering.http://dx.doi.org/10.1016/j.ijproman.2009.03.004

[16]. Gibson, C.F. (2003). IT-Enabled Business Change: An approach to understanding and managing risk, MIS Quarterly Executive.

[17]. Cohen, A., and Golan, R. (2007). Predicting absenteeism and turnover intentions by past absenteeism and work attitudes. Career Development International, 12(5), 416-432.

[18]. Donalek, J.G. (2005). Demystifying Nursing Research.The interview in qualitative Research, Vol. $25(2)$, p.124.

[19]. Hellriegel, D., Jackson, S.E., Slocum, J., Staunde, G., Amos,T., Klopper, H.B., Louw, L., and Oosthuizen, T. (2009). Management, 3rd Edition. Oxford University Press, Southern Africa.

[20]. Markus, M.L. (2004). Techno change Management. Using IT to drive organisational change. Journal of Information Technology. Volume (19), pp.3-19.

[21]. Bergh, Z. and Geldenhuys, D. (2014). Psychology in the work context, 5th Edition. Oxford University Press. Southern Africa 
[22]. Heizer, J. and Render, B. (2011).Operations Management, $10^{\text {th }}$ ed. Prentice Hall. New Jersey. U.S.A.

[23]. Laudon, K. C. and Laudon, J. P. (2006). Management information system: Managing the digital firm. 10 Ed).Prentice Hall, Upper Saddle River. New Jersey.

[24]. Rosen, C.C., Chang, C., Johnson, R.E., and Levy, P.E. (2009). Perceptions of the organisational context and psychological contract breach: Assessing competing perspectives. Organisational Behavior and Human Decision Processes, 108: 202-217.

[25]. Fishbein, M., and Ajzen, I. (2010). Predicting and changing behavior. The reactioned action approach. New York psychology press (Taylor and Francis)

[26]. Rothmann, S., and Cooper, C.L. (2008). Organisational and work psychology. London: Hodder Education.

[27]. Judge, T.A., Piccolo, R.F., Podsakoff, N.P., Shaw, J.C., and Rich; B.L (2010). The Relationship between pay and job satisfaction. A Meta-analysis of the literature. A Journal of vocational behavior, 77 (2), 157 - 167. Doi. 10.1016/ jjvb.2010.04.002.

[28]. Kaliski, B.S. (2007). Encyclopaedia of Business and Finance, Section edition, Thompson Gale, Detroit, p.446

[29]. Sempane, M.E., Rieger, H.S. and Roodt, G. (2002) Job Satisfaction in relation to organizational culture. SA Journal of industrial Psychology; 28 (2). 23 - 30. https://doi.org/10.4102/sajip.v28:2.49

[30]. Kassin, S. (2006). Kassin in modules. Upper Saddle River: Pearson Prentice Hall.

[31]. Rickli, J (2010), Negotiating otherness in the Dutch Protestant World. Missionary and diaconal encounters between Protestant church in the Netherlands and organisations Phd. Differentiation: Netherlands, Amsterdam

[32]. Taylor, J., Bradley, S. and Nguyen, A.N. (2003). Job autonomy and Job satisfaction: New (Economics, working paper series), Lancaster University. The Department of Economics.

[33]. Jawahar, I.M., and Hemmasi, .P. (2006). Perceived organisational support for women's advancement and turnover intentions: The mediating role of job and employer satisfaction, Women in Management Review, Vol. 21 Iss: 8, pp.643 - 661. Retrieved from: http:www.emeraldinsight.com/author/hemmasi,+ pegah Field, J. (2008).

[34]. Job Satisfaction Model. Retrieved from http://talentedapps.wordpress.com/2008/04/11/job-satisfaction-model-for-retention/.

[35]. Hall, R, (2004): Land Restitution in SA Rights, development and the restrained state. Canadian journal of African Studies 38 93) Special Rescue on ten years of democracy in Southern Africa

[36]. Greenberg J. and Baron A.R. (2003) Behaviour in Organisations, Prentice Hall, Vol. 8, pp. 188-215

[37]. Hirtz, P. D., Murray, S. L. \& Riordan, C. A. 2007. The effects of leadership on quality. Engineering Management Journal, 19(1), $22-27$

[38]. Cascio, W. F. (2005). From business partner to driving business success. The next step in the evolution of the HR management. Human resource management. 44:159-163. Doi:10.1002/hrm.20058.

[39]. Acker, G.M. (2011). Burnout among mental health care providers. Journal of Social Work.Vol.12 No.5, pp.475-490.

[40]. Marcus, J. and Van Dam, N. (2007). Organisation and Management. An international Approach. First edition. Routledge

[41]. Mount, M.K., Lies, R., and Johnson, E. (2006). Relationship of personality traits and counter productive work behaviors. The meditating effects of job satisfaction. Personnel Psychology, 59.591-662.

[42]. Kiley, J.D. (2011a) Workplace motivation and emotion. In Bergh and Geldenhuys

[43]. Gautam, M., Mandal, K. and Dalal, R.S. (2006). Job satisfaction of faculty members of veterinary sciences: an analysis. Livestock Research for Rural Development 18 (7).

[44]. Blyton, P. and Jenkins, J. (2007).Key concepts in work: Los Angeles, California; London: Sage.

[45]. Hussami, M. A. (2008). A Study of nurses' job satisfaction: The relationship to organisational commitment, perceived organisational support, transactional leadership, transformational leadership, and level of education. European journal of Science and Research, 286-295.

[46]. Luthans, F. (2005).OrganisationalBehaviour.10th Edition, McGraw-Hill.

[47]. Ball, B. (2011).Employee motivation eBook. Available at http: www.yourcoach.be /en/ employee-motivation-eBook/. Accessed on 18 March 2014.

[48]. Ranjan Ray and Kompal Sinha, (2011). "Interaction between HIV Awareness, Knowledge, Safe Sex Practice and HIV Incidence: Evidence from Botswana," Monash Economics Working Papers 12-11, Monash University, Department of Economics. Retrieved from: https://ideas.reepec.org/p/mos/soswps.20111-2012.html.

[49]. Karimi, S. (2008). Affecting Job Satisfaction of Faculty Members of Bu-Ali Sina University, Hamedan, Iran. Scientific and Research Quarterly Journal of Mazandaran University, 23(6):89-104. Retrieved from: http://www.iiste.org/Journals/index.php/EJBM /article/viewFile/16559/16964

[50]. Lane, A.M. (2007). Mood and Human Performance, Conceptual Measurement and Applied Issues. New York: Nova Science Publishers.

[51]. Wall, T. and Stephenson, G. (2007). Herzberg's two-factor theory of job attitudes: A critical evaluation and some fresh evidence. Industrial Relations Journal, 1(3), 41-65.

[52]. Walker, J.R (2007).Introduction to Hospitality Management 4th Edition, Pearson Education Inc.

[53]. Daft, R.L. and Marcic D. (2011). Management: The New Workplace. UK: South Western Cengage Learning.

[54]. Judge, T. A., and Klinger, R. (2007) Job satisfaction: Subjective well-being at work. In M. Eid, and R. Larsen (Eds.), The science of subjective well-being (pp. 393-413). New York, NY: Guilford Publications.

[55]. Barsade, S.G. and Gibson, D.E (2007). Why does affect matter in organisation. Academy of management perspectives, Vol.21, No.1, pp36-59.

[56]. Feist, J., and Feist, G. (2009).Theories of personality (7thEd).New York, NY: McGraw Hill

[57]. Bergh, Z. C., and Theron, A.L., (2009). Psychology in the work context (4th Ed.). Cape Town, South Africa: Oxford University Press.

[58]. Zaidi, S. (2009). Main drivers of income inequality in Central European and Baltic countries: some insights from recent household survey data. World Bank Policy Research Working Paper, No. 4815. World Bank, Washington, D. C.

[59]. Robbins, S.P. Odendaal, A., and Roodt, G. (2003).Organisational behaviour (9th ed.). Cape Town: Prentice-Hall International.

[60]. Montana, P.J., and Charnov, B.H. (2008). Management (Barron's Business Review Series), Barron's Educational Series; 4 edition

[61]. DeCenzo, D. A. and Robbins, S. P. (2004). Fundamentals of Human Resource Management. (8th Ed.). USA: John Wiley and Sons, Inc.

[62]. Price, J.L. (2007). Connections of orbital cortex. In D.H. Zaid and S.L. Rauch (Eds). The orbitofrontal cortex (p.38-56). New York. Oxford University Press.

[63]. Latham, G.P. and Budwork, M.H. (2007). A theory of goal setting and task performance, Prentice Hall

[64]. Shajahan, D. S. and Shajahan, L. (2004) Organisation behavior. New Age International Publications. 
[65]. Miller, H. and Rosse, J. (2002a). Emotional reserve and adaptation to job dissatisfaction. In J. M. Brett and F. Drasgow (Eds.), The Psychology of Work: Theoretically Based Empirical Research. Hillsdale, NJ: Erlbaum

[66]. Nelson, D.L. and Quick, J.C. (2008). Organisational behavior. Science, the real world and you. 8th edition. South Western. Cengage learning.

[67]. Farndale, E., Van Ruiten, J., Kelliher, C. and Hope-Hailey, V. (2011), the influence of perceived employee voice on organisational commitment: An exchange perspective. Human Resource Management. 50: 113-129. doi:10.1002/hrm.20404

[68]. Frank, F. D., Finnegan, R. P., and Taylor, C. R. (2004). "The Race for Talent: Retaining and Engaging Workers in the 21st Century." Human Resource Planning, Volume 27:3: 12-25.

[69]. Ayeni, C. O., and Popoola, S. O. (2007). "Work Motivation, Job Satisfaction, and Organisational Commitment of Library Personnel in Academic and Research Libraries in Oyo State, Nigeria', Library Philosophy and Practice 2007.

[70]. Christen, M., Cryler, G. and Soberman, D. (2005). Job satisfaction, Job performance and effort. A re-examination. Working paper serious. Retrieved from: https://sites.insead.edu>research $>$ doc.

[71]. Wiid, J., and Diggines, C. (2013), Marketing Research, Second edition. Cape Town, South Africa: Juta \& Company Ltd.

[72]. Babbie, E. (2001). The Practice of Social Research. 9th edition. Belmont: Wadsworth.

[73]. Brynard, P.A. and Hanekom, S.X., (2005). Introduction to research in public administration and related disciplines. Paarl. Van Schaik Academic Hatfield.

[74]. Steyn, A.G.W., Smit, C.F, .Du Toit, S.H.C., and Strasheim, C. (2007). Modern Statistics in Practice. J.L.Van Schaik Academic, Hatfield Pretoria.

[75]. O'Leary Z. (2004). The Essential Guide to Doing Research, London: SAGE Publications Ltd

[76]. De Vos, A.S. Strydom, H. Fouche, C.B. \& Delport, C.S.L. (2011).Research at Grass roots third edition. Pretoria, South Africa: Juta and Co, Ltd.

[77]. McLeod, S.A. (2014). Questionnaires. Retrieved from http://www.simplypschology.org/questionnaires.html

[78]. Flick, U. (2006).An introduction to qualitative research. London: Sage.

[79]. Zikmund, W.G. (2003) Business Research Methods. 7th Edition, Thomson South Western, Ohio.

[80]. Saunders, M., Lewis, P. and Thornhill, A. (2012) Research methods for business students, 6th ed., Harlow, Pearson Education.

[81]. Anderson, V. (2004). Research Methods in Human Resource Management. First edition. Chartered Institute of Personnel Development. Published by the Chartered Institute of Personnel development CIPD House, Camp Road, London.

[82]. Polit, D. F., and Beck, C. T., (2012). Nursing Research: Generating and Assessing Evidence for Nursing Practice. (9th ed.). Philadelphia: Wolters Kluwer.

[83]. Bless, C., Higson-Smith, C., and Kagee, A. (2006). Fundamentals of Social Research Methods. An African Perspective (4thEd.). Cape Town, South Africa: Juta \& Co. Ltd. 